\section{The implementation of the five keys to safer food in campus cafeterias and the effects on Escherichia coli contamination}

\author{
Dewi Susanna, ${ }^{1}$ Aria Kusuma, ${ }^{2}$ \\ Tiara Mairani, ${ }^{1}$ Lassie Fitria ${ }^{1}$ \\ ${ }^{1}$ Faculty of Public Health, Department \\ of Environmental Health, Universitas \\ Indonesia; ${ }^{2}$ Center of Public Health \\ Intervention Technology, National \\ Institute of Health Research and \\ Development, Ministry of Health, \\ Indonesia
}

\begin{abstract}
The World Health Organization developed five keys to safer food's guidelines. This study aimed to determine the relationships between food handlers' knowledge, attitudes, and behavior to the guideline and Escherichia coli (E. coli) contamination of food served at campus cafeterias. This cross-sectional study was carried out by interviewing 98 food handlers selling food and by testing samples for $E$. coli. The dependent variable was $E$. coli contamination, while the independent variables were the knowledge, attitudes, and behavior of food handlers based on the guideline. Each independent variable had five sub-variables that corresponded to the guideline. The data were analyzed using chisquare and logistic regression tests. The results showed that food handlers' knowledge of cooking food thoroughly was significantly related to $E$. coli contamination $(\mathrm{P}=0.54[\mathrm{P}<0.05] ; \mathrm{OR}=2.990 ; 95 \% \mathrm{CI}: 1.093-$ 8.180). Furthermore, the food handlers' attitudes toward cooking food thoroughly were related to $E$. coli contamination $(\mathrm{P}=0.58[\mathrm{P}<0.05] ; \mathrm{OR}=0.385 ; 95 \% \mathrm{CI}: 0.157-$ $0.944)$. There were two factors related to $E$. coli contamination: the food handlers' knowledge of and attitudes toward the third key of the five keys to food safety.
\end{abstract}

\section{Introduction}

In 2011, study results showed a correlation between food consumers' inadequate knowledge of food that could be a source of diseases and food handlers' low awareness of the importance of handwashing when serving food. The study recommended that cafeteria managers and the local government work together to improve food handlers' knowledge and attitudes in campus environments (Susanna et al., 2015).
Another study found that 40 types of raw food materials were nine times more likely to have increased E. coli contamination during storage, and some fresh food materials were also served as a salad or as toppings in some food menu items served at cafeterias (Susanna et al., 2015). Another study also found that raw food material that was not washed with running water and vegetables that were not washed before being used that served at a cafeteria were five times more likely to have $E$. coli contamination (Eryando et al., 2015).

Escherichia. coli bacteria naturally live in the intestinal tracts of humans and warmblooded animals (Marriott et al., 2006; WHO, 2016). The bacteria can live at 8 $44.5^{\circ} \mathrm{C}$. The optimum temperature needed for $E$. coli to grow and develop is $30-42^{\circ} \mathrm{C}$ and the optimum $\mathrm{pH}$ is 5.5-7.5 (Marriott et al., 2006). E. coli contamination occurs, both directly and indirectly, through exposure to excreta (Prüss et al., 2002). A contamination caused by poor hygiene and sanitation in the processes of growing, harvesting, transporting, and serving food.

Since the 2011 study, several campuses have performed interventions in their cafeteria facilities, such as providing counseling on food management hygiene, upgrading facilities, and changing foodserving mechanisms. Changes in food-serving mechanisms meant that food sellers no longer prepared food at cafeterias. This affected hygiene in cafeterias, as the cafeterias looked cleaner because raw food materials were not prepared and cooked on site. In 2015, another study aimed to determine the relationship of food handlers' knowledge, attitudes, and behavior with $E$. coli contamination of food served at cafeterias. This study was an attempt to monitor bacteriological quality, specifically regarding E. coli contamination, of the food served at Indonesia University campus cafeterias. Pathogenic E. coli is often in the news as a cause of foodborne diseases. Usually, this bacterium lives in the intestines of humans and warm-blooded animals. If this bacterial contamination found in food, it might indicate that fecal contamination has occurred from human or animal feces (FAO, 2011), although these can be eliminated by cooking thoroughly (cooking temperature of $70^{\circ} \mathrm{C}$ ) (WHO, 2011).

The five keys are keeping clean, separating raw and cooked food, cooking thoroughly, keeping food at safe temperatures, and using safe water and raw materials (WHO, 2006). Therefore, in this study, the observation of food sanitation hygiene was conducted by developing five keys to improving food safety.

Some studies found that food safety
Correspondence: Dewi Susanna, Building C 2nd Floor, Department of Environmental Health, Faculty of Public Health, Universitas Indonesia, Depok Campus, Jawa Barat, 16424 Indonesia.

Tel.: + 6221 7863479; +62 8121870252

E-mail: dsusanna@ui.ac.id;

dsusanna2@yahoo.com

Key words: Escherichia coli; cafeteria; food, beverages; five keys to safer food.

Acknowledgements: The authors would like to thank the Directorate of Research and Community Engagement Universitas Indonesia for funding this study through a 'Penelitian Unggulan Perguruan Tinggi' Grant, contract No. 0515/UN2.R12/HKP. 05.00/2015.

Contributions: DS: designing research, data collecting and analyzing, and manuscript writing and finalizing; $\mathrm{AK}$ : data analyzing and manuscript writing; TM: references searching; LF: field coordinator in data collecting.

Conflict of interest: The authors declare no conflict of interest.

Funding: This study was funded by the Directorate of Research and Community Engagement Universitas Indonesia through a PUPT Grant No. 0515/UN2.R12/HKP.05 $.00 / 2015$.

Ethical approval: All procedures performed in studies involving human participants were under the ethical standards of the national research committee approved by the Ethics Committee of Faculty of Public Health, Universitas Indonesia, No. 257 / UN2.F10 / PPM.00.02 / 2017.

Informed consent: Informed consent was obtained from all individual participants included in the study.

Received for publication: 25 December 2019. Revision received: 24 May 2019.

Accepted for publication: 26 May 2020

This work is licensed under a Creative Commons Attribution-NonCommercial 4.0 International License (CC BY-NC 4.0).

(C) Copyright: the Author(s), 2020

Licensee PAGEPress, Italy

Italian Journal of Food Safety 2020; 9:8782

doi:10.4081/ijfs.2020.8782

knowledge is not always in line with practices (Akabanda et al., 2017; Zanin et al., 2017). Almost five years after the previous research, we aim to determine the condition of food safety at campus cafeterias. This article specifically aimed to assess the relationship of food handlers' knowledge, attitudes, and behavior toward 
the five keys to safer food with $E$. coli contamination of food served at the campus cafeteria.

\section{Materials and Methods}

\section{Study area setting}

This study used a cross-sectional design conducted on the campus of a state university in Depok, Jawa Barat, from September to October 2015. The data collected were food handlers' knowledge, attitudes, behavior, and food samples were taken from each cafeteria. The number of samples was 98 food handlers who sell any kind of food and beverages on the campus. The methods applied were interviews with the food handlers, observations of their behavior in preparing food at cafeterias, and testing for $E$. coli in food samples.

\section{Data collecting}

The interview conducted by enumerators were selected students from the Faculty of Public Health at Universitas Indonesia, who was majoring in environmental health. The enumerators were trained before to get the same perception in doing interviews using questionnaires and taking food samples in the field. The aim of the training was also to align their understandings and mechanisms of taking and delivering food samples to ensure that the samples represented.

The area of the interview included observations of food handlers' knowledge, attitudes, and behavior. The knowledge, attitudes, and behavior variables observed during the study were determined based on the World Health Organization's five keys to safer food (WHO, 2006). The variables observed were handwashing and the hygiene of cloths used for cleaning as the first key. For the second key: separating raw and cooked food materials, the different uses of cutting boards and the separation of raw and cooked food materials during preparation observed. For the third key: cooking thoroughly, the variables included food heating and cooking temperature. The fourth key: keeping food at a safe temperature, was examined with the variables of the length of time that cooked food was at room temperature, cooked food management, and safe food storage. For the fifth key: using safe water and materials, the safety of water was assessed, and the washing of fruits and vegetables was observed (WHO, 2006).

The enumerators interviewed each food handler using the questionnaire. There were ten questions for each knowledge, attitude, and behavior variable that corresponded to the five keys to safer the food. For behaviors, the questions were answered based on the observations of food handlers' practices. The enumerators asked food handlers about the most popular food item sold based on their sales before they observed the food handlers' behavior. The enumerators also observed each location and examined the performance of the food handler for each key, starting with handwashing and cleanliness, the location of raw and cooked food storage, the food storage temperature, the preparation of food, the use of cutting boards and food utensils, the cooking temperature, and the serving temperature of the food in each menu item that they served to consumers in their locations. They also observed the physical qualities of the water used for preparation and cooking to assess cleanliness. Samples collected from only one menu item from each location.

\section{Laboratory analysis}

The enumerators also took food samples from each cafeteria. Food samples were taken aseptically, placed into sample containers, which were then labeled, closed tightly, placed in a collection jar, and packed in ice, then sent to a laboratory for analysis.

Food samples were stirred evenly, chopped, and then weighed based on needs. The weighed food samples placed into an Erlenmeyer flask containing sterile aqua dest $\left(10^{-1}\right.$ dilution). The ratio of the weight of the food samples to sterile aqua dest was 1:10. From the Erlenmeyer flask containing the $10^{-1}$ dilution, $1 \mathrm{~mL}$ was removed and placed into a test tube containing $9 \mathrm{~mL}\left(10^{-2}\right.$ dilution). Dilution continued until the dilution reached $10^{-4}$. In every dilution $\left(10^{-1}\right.$ to $\left.10^{-4}\right), 1 \mathrm{~mL}$ was removed and placed into a tube with eosin-methylene blue agar (EMBA) medium, which had already melted. After dilution, the resulting mixture put into the medium, and homogenization was performed to ensure that the mixture stirred evenly. Each mixture then moved to a petri dish. Thus, there were four Petri dishes for each sample. The Petri-dishes then incubated at $37^{\circ} \mathrm{C}$ for 24 hours. Any colony with a green metallic color indicated $E$. coli bacteria growth on the media. Levels of $E$. coli determined using serial dilutions of the food samples in EMBA medium (FDA, 2017). The sensitivity of this method was less sensitive than the MPN technique to detect the lowest level of E. coli contamination.

Respondents in this study were all the food handlers at the cafeteria locations. If there were more than one food handler at a location, the respondent selected was the food handler who most often had contact with food during preparation and serving. The enumerators determined who had the most contact by asking the food handlers and making simple lists of their duties in the location. There are few workers at each location because they are generally small businesses, so each location usually only employs 1-2 food handlers. The food handlers in every location asked, and only one respondent interviewed in each location. Data collected from September to October 2015. The respondents were all the food handlers who performed food preparation at campus cafeterias.

\section{Data analysis}

The independent variables grouped under three variables: knowledge, attitudes, and behavior. Each variable had five subvariables: key 1 , key 2 , key 3 , key 4, and key 5 , referring to the five keys to safer food (WHO, 2006).

Before the analysis, the data edited and coded. The question responses scored; the score for the correct answer was one (1), and the score for a wrong answer was zero (0). The data were categorized as low risk if the answer was correct (score $=1$ ) and high risk if the answer was wrong ( were two questions for each key for each variable, except for the fourth key for the knowledge variable, which had three questions. If the total score for a key $\geq 1$, it indicated low risk. If the overall score for a key was $<1$, it meant high risk. Only the fourth key for the knowledge variable was different because it assessed with three questions. If the total score for the fourth key was $\geq 2$, it indicated low risk. If the overall score of the fourth key was $<2$, it indicated high risk.

The low and high-risk categories refer to the five keys to safer food theory. Univariate analysis to determine the frequency distributions of the independent and dependent variables. The bivariate analysis was performed to determine the relationship between each independent and dependent variable by a chi-square test using $\alpha=0.05$. Multivariate analysis using a logistic regression test to determine the independent variable most related to the dependent variable.

\section{Results}

There were 98 food and beverage menu items analyzed in this study. The high-risk food menu items were cooked as soup or curry and made of chicken, meat, fish or seafood, fresh vegetables, or fruit. The highrisk drink items were those with milk and coconut milk ingredients. The low-risk food menu items were fried or grilled, and the low-risk drink menu items did not have any high-risk ingredients, such as milk or coconut milk. A total of $54 \%$ of the menu 
items were high-risk menus, and $46 \%$ were low risk.

The laboratory test result, E. coli contamination found in $55.1 \%$ of the examined food samples. The bivariate analysis results on the food handlers' knowledge (Table 1) showed that one independent variable, namely, the knowledge of cooking thoroughly, had a statistically significant relation $(\mathrm{P}=0.049$, $\mathrm{P}<0.05$; OR $=2.947 ; 95 \% \mathrm{CI}: 1.11-7.81)$ to $E$. coli contamination of the food served at the cafeterias. Table 1 Relation between food handlers' knowledge about the five keys to safer food and Escherichia coli contamination of the food served. Bivariate analysis results of food handlers' attitudes showed that only the cooking thoroughly variable had a statistically significant relation to $E$. coli contamination of the food served at the cafeterias (Table 2). Table 2 Relation between food handlers' attitudes towards the five keys to safer food and Escherichia coli contamination of the food served. Bivariate analysis result of food handlers' behavior showed no statistically significant relationship between food handlers' behavior and E. coli contamination of the food served at the cafeterias (Table 3 ).

Multivariate analysis result (Table 4) showed a statistically significant relationship between food handlers' knowledge of cooking thoroughly $(\mathrm{P}=0.03[\mathrm{P}<0.05]$ $\mathrm{OR}=2.947 ; 95 \% \mathrm{CI}: 1.111-7.815)$ and $E$. coli contamination of the food served at the cafeterias. Therefore, knowledge of cooking thoroughly was the factor most related to $E$. coli contamination; food handlers' knowledge was three times more likely than the other factors to affect $E$. coli contamination of the food served at the cafeterias.

Table 1. Relation between food handlers' knowledge about the five keys to safer food and Escherichia coli contamination of the food served.

\begin{tabular}{|c|c|c|c|c|c|c|c|c|c|c|c|}
\hline \multirow[t]{2}{*}{ Independent Variable } & & \multicolumn{4}{|c|}{ E. coli Contamination } & \multicolumn{2}{|c|}{ Total } & \multirow[t]{2}{*}{ p } & \multirow[t]{2}{*}{ OR } & \multicolumn{2}{|c|}{$\begin{array}{l}\text { 95\% Confidence } \\
\text { Interval (CI) }\end{array}$} \\
\hline & & \multicolumn{2}{|c|}{ Contaminated } & \multicolumn{2}{|c|}{ Not Contaminated } & n & $\%$ & & & & \\
\hline $\begin{array}{l}\text { Knowledge about keeping clean (key 1) } \\
\text { Subtotal }\end{array}$ & $\begin{array}{l}\text { High risk } \\
\text { Low risk }\end{array}$ & $\begin{array}{c}2 \\
58 \\
60\end{array}$ & $\begin{array}{l}50.0 \\
61.7 \\
61.2\end{array}$ & $\begin{array}{c}2 \\
36 \\
38\end{array}$ & $\begin{array}{c}50.0 \% \\
38.3 \% \\
38.8\end{array}$ & $\begin{array}{l}4 \\
94 \\
98\end{array}$ & $\begin{array}{l}100.0 \\
100.0 \\
100.0\end{array}$ & 0.638 & 0.621 & 0.08 & 4.60 \\
\hline $\begin{array}{l}\text { Knowledge about separating raw and } \\
\text { cooked food (key 2) } \\
\text { Subtotal }\end{array}$ & $\begin{array}{l}\text { High risk } \\
\text { Low risk }\end{array}$ & $\begin{array}{l}37 \\
23 \\
60\end{array}$ & $\begin{array}{l}62.7 \\
59.0 \\
61.2\end{array}$ & $\begin{array}{l}22 \\
16 \\
38\end{array}$ & $\begin{array}{l}37,3 \\
41.0 \\
38.8\end{array}$ & $\begin{array}{l}59 \\
39 \\
98\end{array}$ & $\begin{array}{l}100.0 \\
100.0 \\
100.0\end{array}$ & 0.873 & 1.170 & 0.51 & 2.68 \\
\hline $\begin{array}{l}\text { Knowledge about cooking thoroughly (key } 3 \text { ) } \\
\text { Subtotal }\end{array}$ & $\begin{array}{l}\text { High risk } \\
\text { Low risk }\end{array}$ & $\begin{array}{c}51 \\
9 \\
60\end{array}$ & $\begin{array}{l}67.1 \\
40.9 \\
61.2\end{array}$ & $\begin{array}{l}25 \\
13 \\
38\end{array}$ & $\begin{array}{l}32.9 \\
59.1 \\
38.8\end{array}$ & $\begin{array}{l}76 \\
22 \\
98\end{array}$ & $\begin{array}{l}100.0 \\
100.0 \\
100.0\end{array}$ & 0.049 & 2.947 & 1.11 & 7.81 \\
\hline $\begin{array}{l}\text { Knowledge about keeping food at safe } \\
\text { temperatures (key 4) } \\
\text { Subtotal }\end{array}$ & $\begin{array}{l}\text { High risk } \\
\text { Low risk }\end{array}$ & $\begin{array}{c}53 \\
7 \\
60\end{array}$ & $\begin{array}{l}61.6 \\
58.3 \\
61.2\end{array}$ & $\begin{array}{c}33 \\
5 \\
38\end{array}$ & $\begin{array}{l}38.4 \\
41.7 \\
38.8\end{array}$ & $\begin{array}{l}86 \\
12 \\
98\end{array}$ & $\begin{array}{l}100.0 \\
100.0 \\
100.0\end{array}$ & 1.000 & 1.147 & 0.34 & 3.91 \\
\hline $\begin{array}{l}\text { Knowledge about using safe water and } \\
\text { raw materials (key } 5 \text { ) } \\
\text { Subtotal }\end{array}$ & $\begin{array}{l}\text { High risk } \\
\text { Low risk }\end{array}$ & $\begin{array}{l}50 \\
10 \\
60\end{array}$ & $\begin{array}{l}62.5 \\
55.6 \\
61.2\end{array}$ & $\begin{array}{c}30 \\
8 \\
38\end{array}$ & $\begin{array}{l}37.5 \\
44.4 \\
38.8\end{array}$ & $\begin{array}{l}80 \\
18 \\
98\end{array}$ & $\begin{array}{l}100.0 \\
100.0 \\
100.0\end{array}$ & 0.781 & 1.333 & 0.47 & 3.75 \\
\hline
\end{tabular}

Table 2 Relation between food handlers' attitudes towards the five keys to safer food and Escherichia coli contamination of the food served.

\begin{tabular}{|c|c|c|c|c|c|c|c|c|c|c|c|}
\hline \multirow[t]{2}{*}{ Independent Variable } & & \multicolumn{4}{|c|}{ E. coli Contamination } & \multicolumn{2}{|c|}{ Total } & \multirow[t]{2}{*}{ p } & \multirow[t]{2}{*}{ OR } & \multicolumn{2}{|c|}{$\begin{array}{l}\text { 95\% Confidence } \\
\text { Interval (CI) }\end{array}$} \\
\hline & & Contaminated & $\begin{array}{l}\text { nated } \\
\%\end{array}$ & \multicolumn{2}{|c|}{ Not Contaminated } & n & $\%$ & & & & \\
\hline $\begin{array}{l}\text { Attitudes towards keeping clean (key 1) } \\
\text { Subtotal }\end{array}$ & $\begin{array}{l}\text { High risk } \\
\text { Low risk }\end{array}$ & $\begin{array}{l}22 \\
38 \\
60\end{array}$ & $\begin{array}{l}52.4 \\
67.9 \\
61.2\end{array}$ & $\begin{array}{l}20 \\
18 \\
38\end{array}$ & $\begin{array}{l}47.6 \\
32.1 \\
38.8\end{array}$ & $\begin{array}{l}42 \\
56 \\
98\end{array}$ & $\begin{array}{l}100.0 \\
100.0 \\
100.0\end{array}$ & 0.178 & 0.521 & $0.228-$ & 1.189 \\
\hline $\begin{array}{l}\text { Attitudes towards separating raw and } \\
\text { cooked food (key 2) } \\
\text { Subtotal }\end{array}$ & $\begin{array}{l}\text { High risk } \\
\text { Low risk }\end{array}$ & $\begin{array}{l}21 \\
39 \\
60 \\
\end{array}$ & $\begin{array}{l}58.3 \\
62.9 \\
61.2 \\
\end{array}$ & $\begin{array}{l}15 \\
23 \\
38\end{array}$ & $\begin{array}{l}41.7 \\
37.1 \\
38.8 \\
\end{array}$ & $\begin{array}{l}36 \\
62 \\
98 \\
\end{array}$ & $\begin{array}{l}100.0 \\
100.0 \\
100.0\end{array}$ & 0.816 & 0.826 & $0.357-$ & 1.911 \\
\hline $\begin{array}{l}\text { Attitudes towards cooking thoroughly (key } 3 \text { ) } \\
\text { Subtotal }\end{array}$ & $\begin{array}{l}\text { High risk } \\
\text { Low risk }\end{array}$ & $\begin{array}{l}31 \\
29 \\
60\end{array}$ & $\begin{array}{l}53.4 \\
72.5 \\
61.2\end{array}$ & $\begin{array}{l}27 \\
11 \\
38\end{array}$ & $\begin{array}{l}46.6 \\
27.5 \\
38.8\end{array}$ & $\begin{array}{l}58 \\
40 \\
98\end{array}$ & $\begin{array}{l}100.0 \\
100.0 \\
100.0\end{array}$ & 0.091 & 0.436 & $0.183-$ & 1.034 \\
\hline $\begin{array}{l}\text { Attitudes towards keeping food at safe } \\
\text { temperatures (key 4) } \\
\text { Subtotal }\end{array}$ & $\begin{array}{l}\text { High risk } \\
\text { Low risk }\end{array}$ & $\begin{array}{c}53 \\
7 \\
60 \\
\end{array}$ & $\begin{array}{l}60.9 \\
63.6 \\
61.2 \\
\end{array}$ & $\begin{array}{c}34 \\
4 \\
38 \\
\end{array}$ & $\begin{array}{l}39.1 \\
36.4 \\
38.8 \\
\end{array}$ & $\begin{array}{l}87 \\
11 \\
98 \\
\end{array}$ & $\begin{array}{l}100.0 \\
100.0 \\
100.0 \\
\end{array}$ & 1.000 & 0.891 & $0.242-$ & 3.274 \\
\hline $\begin{array}{l}\text { Attitudes towards using safe water and } \\
\text { raw materials (key 5) } \\
\text { Subtotal }\end{array}$ & $\begin{array}{l}\text { High risk } \\
\text { Low risk }\end{array}$ & $\begin{array}{c}1 \\
59 \\
60 \\
\end{array}$ & $\begin{array}{l}50.0 \\
61.5 \\
61.2 \\
\end{array}$ & $\begin{array}{c}1 \\
37 \\
38 \\
\end{array}$ & $\begin{array}{l}50.0 \\
38.5 \\
38.8 \\
\end{array}$ & $\begin{array}{l}2 \\
96 \\
98 \\
\end{array}$ & $\begin{array}{l}100.0 \\
100.0 \\
100.0 \\
\end{array}$ & 0.742 & 0.627 & 0.038 & 10.335 \\
\hline
\end{tabular}


respondents with good knowledge of food safety was relatively low, most respondents $(86.5 \%)$ reported that they were able to prepare safe and healthy food (Majowicz et al., 2016). A study in Portugal also found similar results; that is, food handlers' knowledge of cooking temperature was relatively low (Martins et al., 2012). Cooking thoroughly, as one of the five keys to safer food, is important to minimize bacterial contamination, especially with $E$. coli, of food. One of the indicators for cooking thoroughly is cooking temperature. The safe cooking temperature is above $70^{\circ} \mathrm{C}$ (WHO, 2006). If food cooked at this temperature, then all types of $E$. coli in food are destroyed because it can only grow and develop between $8-44.5^{\circ} \mathrm{C}$. A study found that in-ground beef baked at a temperature of $71.1^{\circ} \mathrm{C}$ with even heat, E. coli O157: H7 was not found in significant amounts (Rhee et al., 2003). If food handlers do not know safe temperatures for cooking food thoroughly, then the food may be cooked to unsafe temperatures. This could potentially cause food to be dangerous due to E. coli contamination.

A study in Egypt found that $100 \%$ of vegetables sold in an Alexandria market were potentially contaminated by $E$. coli, as the vegetables sold by street vendors located in open spaces in unsanitary environments, and their transport was also not sanitary (Khalil and Gomaa, 2014). Another study found Shiga toxin-producing $E$. coli on vegetables sold in markets in Alexandria (Khalil et al., 2015). If vegetables are grown using manure, they are possibly already contaminated by E. coli. A study in Nigeria found that $50 \%$ of 336 irrigation water samples used for farming contaminated by E. coli $>126 \mathrm{MPN} / 100$. The median value of $E$. coli contamination of tomatoes sold in a supermarket was $2.66 \mathrm{Log} \mathrm{MP} / \mathrm{g}$, which was higher than the contamination levels of tomatoes in farming areas (0.92 Log MPN/g) (Shenge et al., 2015). These studies suggest that $E$. coli contamination can occur in raw materials. Furthermore, a study in the United State found that $38.7 \%$ of 212 chicken samples were contaminated by $E$. coli, and $E$. coli also infected $19 \%$ of beef samples (ZHao et al., 2001). The studies showed that even in a country with a good food safety system, there are still $E$. coli-contaminated food materials sold in the market.

Food sellers in this study generally buy food materials in traditional markets with sanitation conditions that are much worse than those of supermarkets; thus, the risk of $E$. coli contamination of raw food materials is quite high. Therefore, the cooking stage particularly regarding safe cool temperatures. Although the proportion of

Table 3. Relation between food handlers' behavior related to the five keys to safer food and Escherichia coli contamination of the food served.

\begin{tabular}{|c|c|c|c|c|c|c|c|c|c|c|c|}
\hline \multirow[t]{2}{*}{ Independent Variable } & & \multicolumn{4}{|c|}{ E. coli Contamination } & & \multirow[t]{2}{*}{ p } & \multirow[t]{2}{*}{ OR } & \multicolumn{2}{|c|}{$\begin{array}{l}95 \% \text { Confidence } \\
\text { Interval (CI) }\end{array}$} \\
\hline & & \multicolumn{2}{|c|}{ Contaminated } & \multicolumn{2}{|c|}{ Not Contaminated } & n & $\%$ & & & & \\
\hline $\begin{array}{l}\text { Behavior related to keeping clean (key 1) } \\
\text { Subtotal }\end{array}$ & $\begin{array}{l}\text { High risk } \\
\text { Low risk }\end{array}$ & $\begin{array}{c}2 \\
58 \\
60\end{array}$ & $\begin{array}{l}66.7 \\
61.1 \\
61.2\end{array}$ & $\begin{array}{c}1 \\
37 \\
38\end{array}$ & $\begin{array}{l}33.3 \\
38.9 \\
38.8\end{array}$ & $\begin{array}{c}3 \\
95 \\
98\end{array}$ & $\begin{array}{l}100.0 \\
100.0 \\
100.0\end{array}$ & 0.844 & 1.276 & $0.112-$ & 14.574 \\
\hline $\begin{array}{l}\text { Behavior related to separating raw and } \\
\text { cooked food (key 2) } \\
\text { Subtotal }\end{array}$ & $\begin{array}{l}\text { High risk } \\
\text { Low risk }\end{array}$ & $\begin{array}{c}2 \\
58 \\
60\end{array}$ & $\begin{array}{l}50.0 \\
61.7 \\
61.2\end{array}$ & $\begin{array}{c}2 \\
36 \\
38\end{array}$ & $\begin{array}{l}50.0 \\
38.3 \\
38.8\end{array}$ & $\begin{array}{c}4 \\
94 \\
98 \\
\end{array}$ & $\begin{array}{l}100.0 \\
100.0 \\
100.0\end{array}$ & 0.638 & 0.621 & $0.084-$ & 4.60 \\
\hline $\begin{array}{l}\text { Behavior related to cooking thoroughly } \\
\text { (key 3) } \\
\text { Subtotal }\end{array}$ & $\begin{array}{l}\text { High risk } \\
\text { Low risk }\end{array}$ & $\begin{array}{l}11 \\
49 \\
60\end{array}$ & $\begin{array}{l}52.4 \\
63.6 \\
61.2\end{array}$ & $\begin{array}{l}10 \\
28 \\
38\end{array}$ & $\begin{array}{l}47.6 \\
36.4 \\
38.8\end{array}$ & $\begin{array}{l}21 \\
77 \\
98\end{array}$ & $\begin{array}{l}100.0 \\
100.0 \\
100.0\end{array}$ & 0.493 & 0.629 & $0.237-$ & 1.665 \\
\hline $\begin{array}{l}\text { Behavior related to keeping food at safe } \\
\text { temperatures (key 4) } \\
\text { Subtotal }\end{array}$ & $\begin{array}{l}\text { High risk } \\
\text { Low risk }\end{array}$ & $\begin{array}{l}22 \\
38 \\
60\end{array}$ & $\begin{array}{l}59.5 \\
62.3 \\
61.2\end{array}$ & $\begin{array}{l}15 \\
23 \\
38\end{array}$ & $\begin{array}{l}40.5 \\
37.7 \\
38.8 \\
\end{array}$ & $\begin{array}{l}37 \\
61 \\
98 \\
\end{array}$ & $\begin{array}{l}100.0 \\
100.0 \\
100.0\end{array}$ & 0.948 & 0.888 & $0.385-$ & 2.048 \\
\hline $\begin{array}{l}\text { Behavior related to using safe water } \\
\text { and raw materials (key 5) } \\
\text { Subtotal }\end{array}$ & $\begin{array}{l}\text { High risk } \\
\text { Low risk }\end{array}$ & $\begin{array}{c}1 \\
59 \\
60\end{array}$ & $\begin{array}{l}50.0 \\
61.5 \\
61.2\end{array}$ & $\begin{array}{c}1 \\
37 \\
38\end{array}$ & $\begin{array}{l}50.0 \\
38.5 \\
38.8\end{array}$ & $\begin{array}{l}2 \\
96 \\
98\end{array}$ & $\begin{array}{l}100.0 \\
100.0 \\
100.0\end{array}$ & 0.742 & 0.627 & 0.038 & 10.335 \\
\hline
\end{tabular}

Table 4. Final results of the multivariate analysis of food handlers' knowledge and behavior variables most related to Escherichia coli contamination.

$\begin{array}{lccccc} & \text { Variable } & \text { B } & \text { P-value } & \text { OR } & 95 \% \text { Confidence Interval (CI) } \\ \text { Knowledge about cooking thoroughly (key 3) } & 1.081 & 0.030 & 2.947 & 1.111- & 7.815 \\ \text { Constant } & -0.713 & 0.003 & 0.490 & & \end{array}$


could be an effective way to eliminate bacteria in food materials. Several factors must be considered when cooking food, including cooking food until it thoroughly cooked, particularly perishable food such as beef, poultry, eggs, and seafood.

The various thickness and types of meat influenced the necessary cooking temperature (Saha et al., 2019). Therefore, knowledge of cooking thoroughly is important in minimizing $E$. coli contamination of food. Observation of the appropriate cooking temperature for food is much more important than adherence to a certain length of time for cooking. For tenderloin steaks, if the middle part of the meat has reached a temperature of $70^{\circ} \mathrm{C}$ or if it is well done, $90 \%$ of the bacteria that previously existed in the meat can be reduced (Peixoto et al., 2019). Thus, food handlers must measure the cooking temperature when cooking a specific menu item. Furthermore, food handlers can perceive certain changes in food as it is being cooked as indicators that the food has reached a safe temperature in the cooking process. This condition will reduce the risk of $E$. coli contamination of the food.

Every food handler must have knowledge of cooking temperatures and indicators of doneness for the foods they cook. This knowledge can be obtained from food safety training. Then, experience in the implementation of this knowledge will increase the quality of their knowledge, as shown in a study in Nigeria that found that older food handlers have better knowledge than younger food handlers (Mudaki et al., 2016). This strengthening of knowledge through experience is possible in addition to increasing knowledge through training, as older food handlers have more experience than younger food handlers.

In general, knowledge and attitudes usually corresponded. If food handlers' knowledge of thorough cooking is inadequate, their attitudes towards thoroughly cooking are often insufficient as well. A Mauritius University study noted that knowledge was not always in line with behavior. Respondents with good knowledge of food safety did not necessarily show safe behavior in food management (BiranjiaHurdoyal and Latouche, 2016). Therefore, food handlers with inadequate food safety knowledge are unlikely to manage food safely. For example, if $E$. coli bacteria contaminate food materials, such as chicken or other kinds of poultry, during the cleaning of food materials, contaminants will remain in food materials until they cooked. If the food-cooking process performed thoroughly, the bacteria would die while the foods cooked at a temperature higher than $70^{\circ} \mathrm{C}$. A study conducted in the United States found that of 159 beef samples, $53.6 \%$ contaminated by Campylobacter jejuni, Campylobacter contaminated $41.3 \%$, and other bacteria-contaminated 5.1\% (Zhao et al., 2001).

In an integrative review, six databases searched, 253 articles consulted, and 36 original articles included. Half of the articles noted that there was no proper translation of knowledge into attitudes or practices or attitudes into practices after training (Zanin et al., 2017). Based on the study results, it can be seen that the knowledge of food handlers who have participated in training is not necessarily in line with their practices. Moreover, the food handlers observed in this study had not been given training on the five keys to safer food, so, understandably, many food handlers observed still had inadequate knowledge about cooking food thoroughly. Only a few food handlers had participated in safe food management training.

A study in Sarawak also found a relationship of knowledge and training with the hygiene of food handlers (Rahman et al., 2016) This demonstrates that the provision of training can, to an extent, affect the knowledge, attitudes, and behavior of food handlers. Thus, the findings on food handlers can provide suggestions for food sales managers to establish advanced food safety training plans for all food handlers. Such training is expected to improve the knowledge, attitudes, and behavior of food handlers in implementing the five keys to safer food, which will affect the hygiene quality of food served.

Several studies found that good knowledge affects behavior. A study in Brazil showed a positive relation of knowledge with the attitudes and behavior of food handlers (de Souza et al., 2018). Thus, food handlers with good knowledge will have good attitudes and behavior related to daily food management. A study in Kuwait showed that more than half $(63 \%)$ of food handlers had low levels of knowledge of cooking time and temperature. Also, the knowledge, attitudes, and behaviors of food handlers were positively related (Al-Kandari et al., 2019). A study in Ireland showed that few $(28 \%)$ food handlers had not yet participated in food safety training at all. Food handlers' knowledge levels were generally $(81 \%)$ high. This study also found positive relationships between knowledge, attitudes, and behavior (Gruenfrldova et al., 2019). This situation indicates that although there is not always a positive relationship between knowledge and behavior, as observed in several studies, in general, there is still a positive effect of training to improve knowledge, attitudes, and behavior. Also, a positive impact of training on the implementation of the five keys to safer food. If food handlers receive knowledge on this topic, it will be, to a certain extent, positively affect their knowledge, attitudes, and behavior regarding food management.

This study has several limitations, such as not observing the number of $E$. coli colonies and the types of $E$. coli found. Besides this study also did not categorize $E$. coli contamination according to the types of menu items served, so it is unknown what types of items had E. coli contamination.

This examination focused on a qualitative assessment of $E$. coli contamination only in served food, not in each menu item sold in the cafeterias. This method might be a weakness of this study. Therefore, it suggested that future studies investigate $E$. coli quantitatively and determine the types of $E$. coli contamination in each food. The most important thing is also needed to assess that is why almost all variables, except cooking thoroughly, did not have an association with $E$. coli contamination. It could be the variables in almost all keys are not a sensitive indicator in association with $E$. coli contamination.

\section{Conclusions and \\ Recommendations}

Some foods were still found to be contaminated by E. coli (55.1\%). Knowledge of cooking thoroughly was 2.9 times more likely than the other factors to affect the risk of contamination.

A further in-depth study must be conducted that considers why the knowledge of cooking thoroughly is more related than other factors to the risk for $E$. coli contamination of food, as well as why factors other than knowledge, attitudes, and behavior are not related to contamination. Regular educational interventions for food handlers must be developed to expose them to food management safety. Education can be performed every day before starting to perform activities at each cafeteria to remind food handlers always to implement the five keys to safer food.

\section{References}

Al-Kandari D, Al-abdeen J, Sidhu J, 2019. Food safety knowledge, attitudes, and practices of food handlers in restaurants in Kuwait. Food Control 103:103-10.

Akabanda Hlortsi OK, 2017. Food safety knowledge, attitudes, and practices of institutional food-handlers in Ghana. 
BMC Public Health 17:40.

Biranjia-Hurdoyal S LM, 2016. Factors affecting microbial load and profile of potential pathogens and food spoilage bacteria from household kitchen tables. Can J Infect Dis Med Microbiol 3574149.

de Souza CVF, de Azevedo PRM, Seabra LMAJ, 2018. Food safety in Brazilian popular public restaurants: Food handlers' knowledge and practices. J Nutr Heal Food Eng 8:00262.

Eryando T, Susanna D, Kusuma A PD, 2015. Hubungan pemilihan dan pengolahan bahan makanan terhadap kontaminasi Escherichia coli pada penyajian makanan jajanan. Makara J Heal Res 19;41-50.

FAO. Preventing Escherichia coli in food. New York: Food and Agriculture Organization of the United Nations 2011. 16 p. Available from: http://www.fao.org/fileadmin/user_uplo ad/agns/pdf/Preventing_Ecoli.pdf

FDA. BAM 4: Enumeration of Escherichia coli and the Coliform Bacteria [Online]. [Internet]. FDA. 2017. Available from: http://www.fda.gov/Food/FoodScienceR esearch/LaboratoryMethods/ucm064948 htm

Gruenfeldova J, Domijan K, WC, 2019. A study of food safety knowledge, practice, and training among food handlers in Ireland. Food Control 105:131-40.

Khalil R, Gomaa M, 2016. Evaluation of the microbiological quality of conventional and organic leafy greens at the time of purchase from retail markets in Alexandria, Egypt. Pol J Microbiol 63:237-43.

Khalil RK, Gomaa MA, KM, 2015. Detection of Shiga-toxin producing E. coli (STEC) in leafy greens sold at local retail markets in Alexandria, Egypt. Int J Food Microbiol 16;19758-64.
LM, da Cunha DT, de Rosso VV, Capriles VD, SE, 2017. Knowledge, attitudes, and practices of food handlers in food safety: An integrative review. Food Res Int 100:53-6.

Madaki MY, BM, 2016. Food safety knowledge of food vendors of higher educational institutions in Bauchi state, Nigeria. Food Control 106:106703.

Majowicz SE, Diplock KJ, Leatherdale ST, Bredin CT, Rebellato S, Hammond D, Jones-Bitton A, DJ, 2016. Food safety knowledge, attitudes and self-reported practices among Ontario high school students. Can J Public Heal 106.

Marriott, Norman, Gravani RB. Principles of Food Sanitation. New York: Springer Science Business Media, Inc.; 2006. 401 p.

Martins RB, Hogg T, OJ, 2012. Food handlers' knowledge on food hygiene: the case of a catering company in Portugal. Food Control 23:184-90.

Peixoto CR, Armendaris P, GA, 2019. Escherichia coli inactivation on tenderloin beef medallions fried to different degrees of doneness. Food Control 106683:106.

Prüss A, Kay D, Fewtrell L, BJ, 2002. Estimating the burden of disease from water, sanitation, and hygiene at a global level. Env Heal Perspect 110:537-42.

Rahman M, Arif MT, Bakar K, TZ, 2012. Food Safety Knowledge, Attitude, and Hygiene Practices among The Street Food Vendors in Northern Kuching City, Sarawak. Borneo. Available from https://jurcon.ums.edu.my/ojums/index. php/borneo-science/article/view/169

Rhee MS, Lee SY, Hillers VN, McCurdy SM, Kang DH, 2003. Evaluation of consumer-style cooking methods for reduction of Escherichia coli O157: H7 in ground beef. J Food Prot 66:1030-4.

Saha J, Jaroni D, NJ, 2019. Influences of weight and thickness on cooking time required for various mechanically tenderized beef steaks to reach minimum safe internal temperature without resting. LWT 110:365-9.

Shenge KC, Whong CM, Yakubu LL, Omolehin RA, Erbaugh JM, Miller SA, LJ, 2015. Contamination of tomatoes with coliforms and Escherichia coli on farms and in markets of northwest Nigeria. J Food Prot 78:57-64.

Susanna D, Eryando T, Kusuma A, Indrawani YM, Zakianis, 2015. The Correlation Between the Storage of Food Ingredients Before Preparation and Leftover or Unprocessed Ingredient Storage to Escherichia coli Contamination in Campus' Food Service. Int Journal Trop Med 10:10-16. Susanna D, Eryando T, KA, 2015. The Relationship Between Knowledge and Behaviour of Food Handlers to Escherichia coli Contamination in Serving Foods in a Campus. World Appl Sci J 33:1125-31.

WHO. Emergencies preparedness, response: Enterohaemorrhagic Escherichia coliUnited Kingdom Disease. outbreak news 20 July 2016 [Internet]. WHO. 2016 [cited 2017 Jul 4]. Available from: http://www.who.int/csr/don/20-july2016-ehec-uk/en/

WHO. Media centre, Fact sheet: E. coli. Geneva: World Health Organization [Internet]. WHO. 2011 [cited 2017 Mar 12]. Available from: http://www.who.int/ mediacentre/factsheets/fs125/en/

WHO. Five keys to safer food manual. 2006. Available from: https://www.who.int/ foodsafety/publications/consumer/manu al_keys.pdf

Zhao C, Ge B, VJ, 2001. Prevalence of Campylobacter spp., Escherichia coli, and Salmonella serovars in retail chicken, turkey, pork, and beef from the Greater Washington, D.C., area. Appl Env Microbiol 67:5431-6. 